\title{
Summary of Calcine Disposal Development Using Hot Isostatic Pressing
}

K.J. Bateman

E.P. Hart

W.M. McCartin

D.L. Wahlquist

September 2013

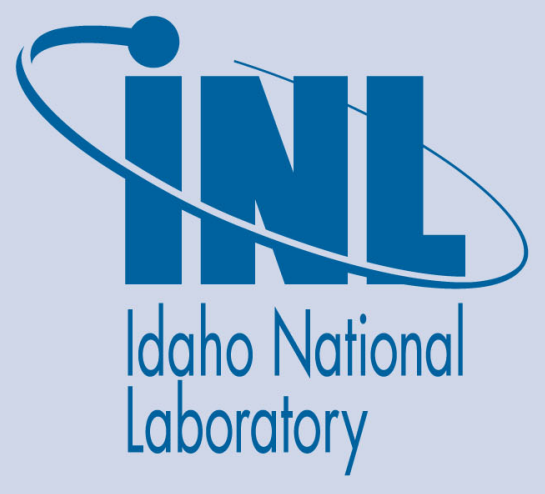

The INL is a U.S. Department of Energy National Laboratory operated by Battelle Energy Alliance 


\section{DISCLAIMER}

This information was prepared as an account of work sponsored by an agency of the U.S. Government. Neither the U.S. Government nor any agency thereof, nor any of their employees, makes any warranty, expressed or implied, or assumes any legal liability or responsibility for the accuracy, completeness, or usefulness, of any information, apparatus, product, or process disclosed, or represents that its use would not infringe privately owned rights. References herein to any specific commercial product, process, or service by trade name, trade mark, manufacturer, or otherwise, do not necessarily constitute or imply its endorsement, recommendation, or favoring by the U.S. Government or any agency thereof. The views and opinions of authors expressed herein do not necessarily state or reflect those of the U.S. Government or any agency thereof. 
INL/EXT-13-30150

Revision 0

\title{
Summary of Calcine Disposal Development Using Hot Isostatic Pressing
}

\author{
K.J. Bateman \\ E.P. Hart \\ W.M. McCartin \\ D.L. Wahlquist
}

September 2013

Idaho National Laboratory Idaho Falls, Idaho 83415

http://www.inl.gov

Prepared for the

U.S. Department of Energy

Office of Environmental Management

Under DOE Idaho Operations Office

Contract DE-AC07-05ID14517 



\begin{abstract}
Battelle Energy Alliance, LLC, has demonstrated the effectiveness of the hot isostatic press (HIP) process for treatment of hazardous high-level waste known as calcine that is stored at the Idaho Nuclear Technology and Engineering Center (INTEC) at Idaho National Laboratory. HIP trials performed with simulated calcines at Idaho National Laboratory's Materials and Fuels Complex and an Australian Nuclear Science and Technology Organization facility from 2007 to 2010 produced a dense, monolithic waste form with increased chemical durability and effective (storage) volume reductions of $\sim 10$ to $\sim 70 \%$ compared to granular calcine forms. In December 2009, the U.S. Department of Energy signed an amended Record of Decision selecting HIP technology as the treatment method for the $4,400 \mathrm{~m}^{3}$ of granular zirconia and alumina calcine stored at INTEC. Testing showed that HIP treatment reduces the risks associated with radioactive and hazardous constituent release, post-production handling, and long-term (repository) storage of calcines and would result in estimated storage cost savings in the billions of dollars. Battelle Energy Alliance has the ability to complete pilot-scale HIP processing of INTEC calcine, which is the next necessary step in implementing HIP processing as a calcine treatment method.
\end{abstract}




\section{CONTENTS}

ABSTRACT iii

ACRONYMS vii

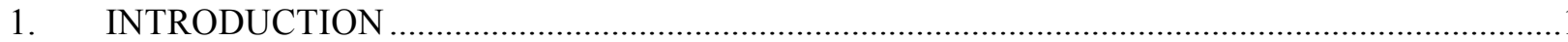

2. HIP INDUSTRIAL BACKGROUND AND PREVIOUS INL WORK …......................................3

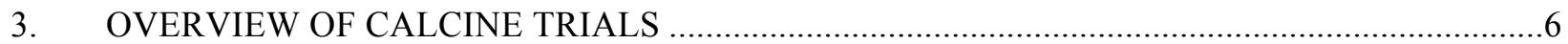

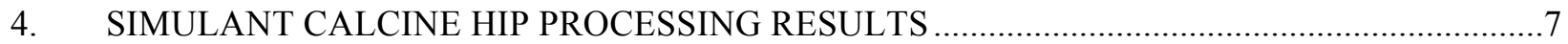

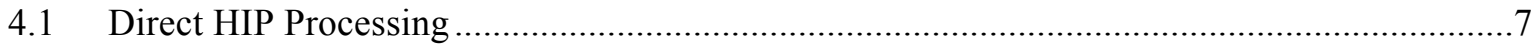

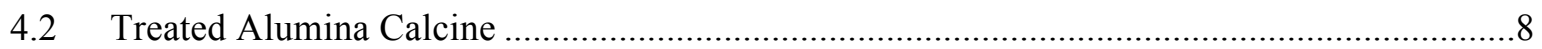

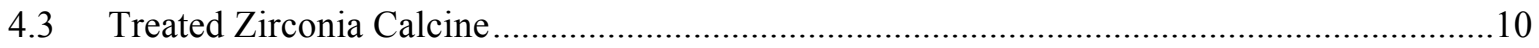

4.4 Scale-Up Testing - Treated Alumina Calcine ...................................................................13

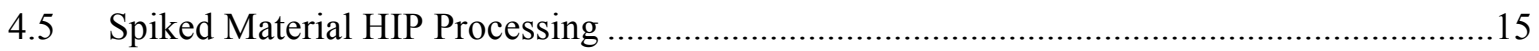

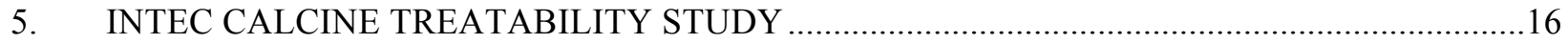

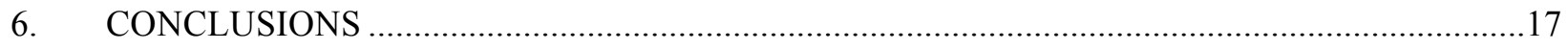

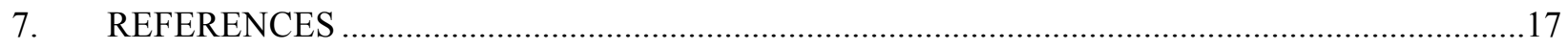

\section{FIGURES}

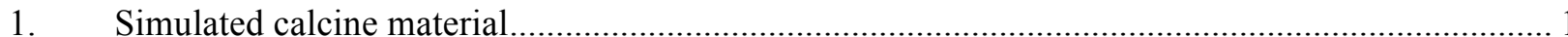

2. INTEC calcine storage. The photograph at top left is the exterior of two of the storage silos. The diagram at top right shows the calcine storage vessel configuration within each silo. The bottom diagram (Patterson and Prather 2004) shows a breakdown of the existing

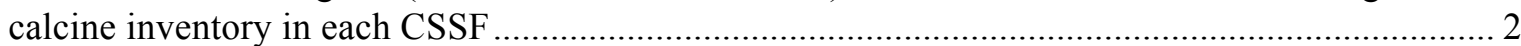

3. Standard HIP schematic (ANSTO and INL 2009) ................................................................ 4

4. Thermal barrier and furnace (upper left). Hydraulic ram (upper right) used to position the yoke over the pressure vessel. HIP installed in the HFEF Hot Cell (bottom) (Bateman,

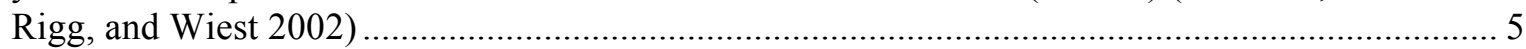

5. Direct HIP-processed alumina calcine simulant (ANSTO and INL 2009) .................................. 8

6. Photograph of treated maximum RCRA alumina simulant calcine sample before and after HIP processing (ANSTO and INL 2009)

7. Photograph of treated maximum RCRA zirconia calcine simulant sample with a $60 \%$ waste loading, produced via a distillation route, before and after HIP processing (ANSTO and INL 2009)

8. Photographs of scale-up treated alumina simulant (from left to right): prior to HIP processing, after HIP processing, and sectioned after HIP processing (ANSTO and INL 2009) 
9. Photographs of industrial-scale treated alumina simulant prior to HIP processing (left) and after HIP processing (right)

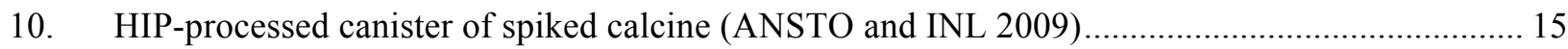

11. CSS 978 contents as seen in 2003. Note the loose calcine and debris visible in the photograph in the middle and to the right.

\section{TABLES}

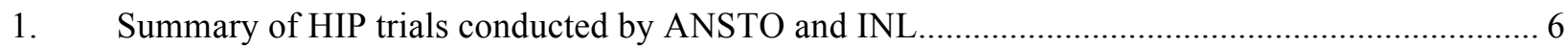

2. Summary of surrogate calcine direct HIP trials (ANSTO and INL 2009) .................................. 7

3. Summary of treated alumina calcine simulant HIP trials (ANSTO and INL 2009) ..................... 9

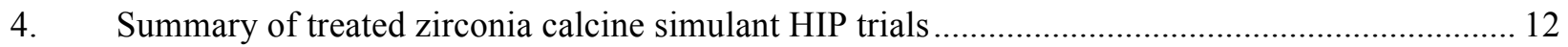

5. Summary of treated alumina calcine scale-up trials (ANSTO and INL 2009) ............................ 14 


\section{ACRONYMS}

ANSTO Australian Nuclear Science and Technology Organization

BEA Battelle Energy Alliance, LLC

CSS calcine sample storage

CSSF Calcined Solids Storage Facility

CWI CH2M-WG Idaho

DOE U.S. Department of Energy

EA environmental assessment

EIS Environmental Impact Statement

HFEF Hot Fuel Examination Facility

HIP hot isostatic press

HLW high-level waste

INL Idaho National Laboratory

INTEC Idaho Nuclear Technology and Engineering Center

MFC Materials and Fuels Complex

PCT Product Consistency Test

RCRA Resource Conservation and Recovery Act

ROD Record of Decision

SNF spent nuclear fuel

TCLP Toxicity Characteristic Leaching Procedure

UTS Universal Treatment Standard 


\section{Summary of Calcine Disposal Development Using Hot Isostatic Pressing}

\section{INTRODUCTION}

This document presents an overview of the research and development of the hot isostatic press (HIP) process as the preferred alternative for stabilization of Idaho National Laboratory (INL) calcine waste prior to disposal.

Calcine was produced from 1953 to 1992 at the Idaho Chemical Processing Plant, later renamed the Idaho Nuclear Technology and Engineering Center (INTEC), as a waste by-product of spent nuclear fuel (SNF) reprocessing activities (75 FR 1). In order to recover highly enriched uranium and other nuclear by-products, SNF was dissolved and the materials of interest were extracted. The liquid waste by-product (raffinate) from the extraction process was pumped into storage tanks and later solidified at INL's New Waste Calcining Facility into calcine, a granular metal oxide (aluminum or zirconium) solid with an average particle size of $0.4 \mathrm{~mm}$ (Figure 1). Calcine was pneumatically transferred into six Calcined Solids Storage Facilities (CSSFs) at INTEC. The storage silos are constructed of reinforced concrete and are typically $80 \mathrm{ft}$ tall by $60 \mathrm{ft}$ in diameter (Figure 2), with the exception of CSSF 1, which is rectangular in shape. Each silo contains seven upright calcine storage vessels that are approximately $12 \mathrm{ft}$ in diameter and $55 \mathrm{ft}$ tall (Figure 2). CSSFs 1 through 5 are filled to capacity; CSSF 6 is approximately half full. Approximately, $4,400 \mathrm{~m}^{3}$ of calcine is stored at INTEC (Patterson and Prather 2004).

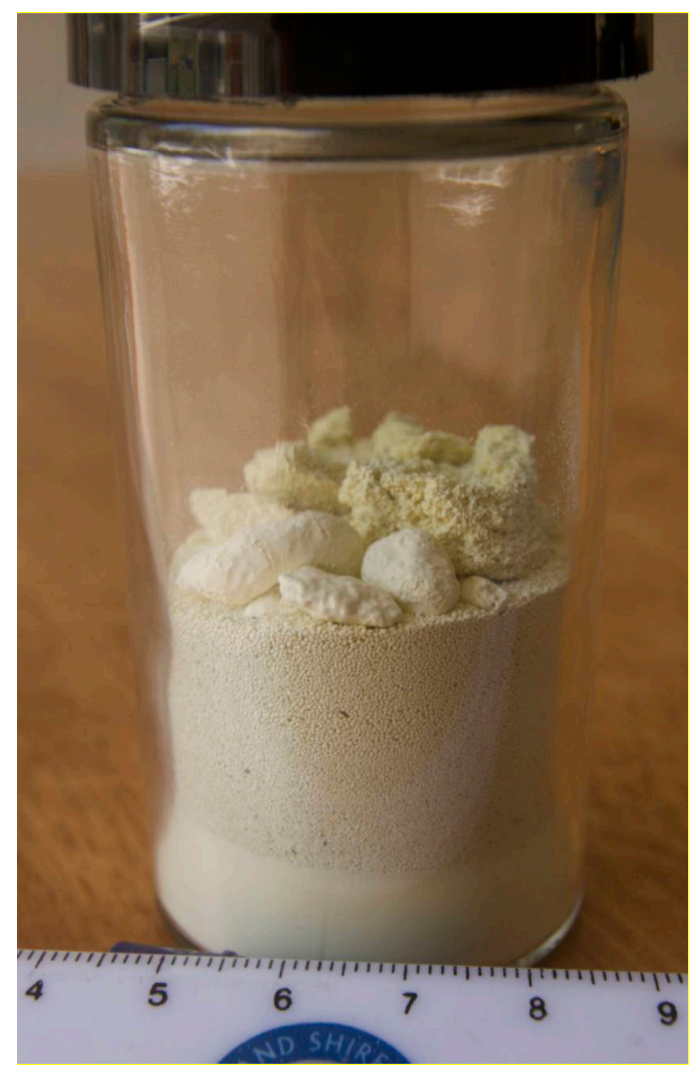

Figure 1. Simulated calcine material. 

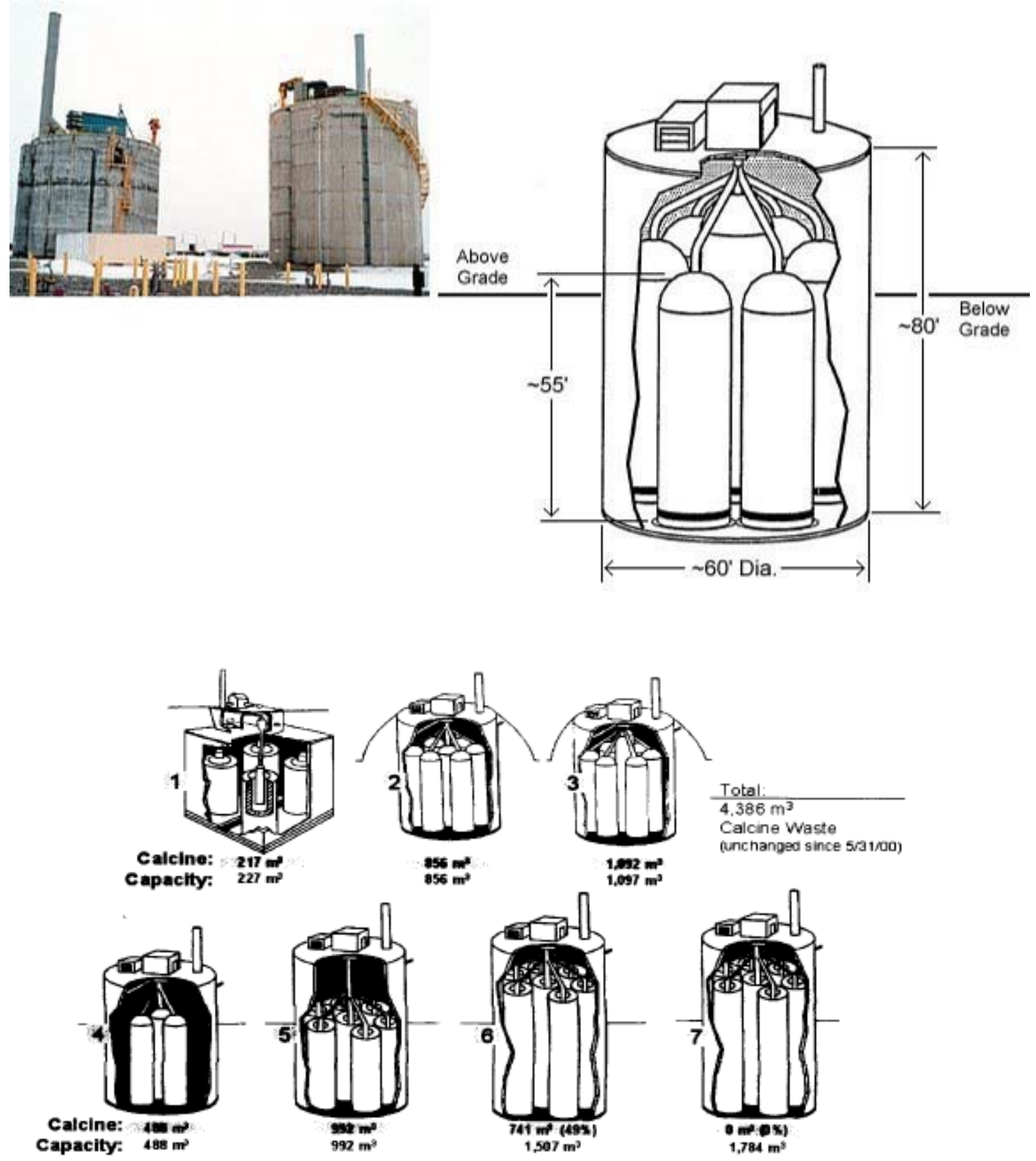

Figure 2. INTEC calcine storage. The photograph at top left is the exterior of two of the storage silos. The diagram at top right shows the calcine storage vessel configuration within each silo. The bottom diagram (Patterson and Prather 2004) shows a breakdown of the existing calcine inventory in each CSSF.

Chemical analysis of INTEC calcine has been performed on samples from New Waste Calcining Facility Campaigns H-3 (1993) and H-4 (1998) and alumina and zirconia calcine from CSSF 2 (1978). The results of the analysis classified calcine as a hazardous waste under the Resource Conservation and Recovery Act (RCRA) (40 CFR 261; 42 USC $\S 6901$ et seq.) due to the spent solvents (Waste Numbers F001, F002, and, F005) and discarded hydrogen fluoride (Hazardous Waste Number U134) content. Additionally, calcine exhibits hazardous waste characteristics for metals toxicity (Waste Numbers D004 through D011). And finally, because of its source, calcine is defined as high-level waste (HLW) by the 
Nuclear Waste Policy Act (42 USC § 10101) and U.S. Department of Energy (DOE) Order 435.1 Chg. 1, "Radioactive Waste Management." As such, calcine waste must be disposed of by placement in a deep geological repository and managed in accordance with RCRA regulations. Solidified calcine was originally intended to be a long-term intermediate HLW form. However, additional treatment is necessary to immobilize the radionuclides present in calcine into a leach-resistant waste form suitable for disposal in a repository (Nelson and Vinjamuri 1995).

The results of HIP trials on simulated zirconia calcine presented by the Australian Nuclear Science and Technology Organization (ANSTO) at the 2005 Waste Management Conference showed that use of the HIP process was a promising method for both reducing the volume of INTEC calcine and for improving the durability of the waste form, qualities that reduce both the cost and the risks associated with transportation and disposal (Begg et al. 2005). Additional HIP trials using surrogate alumina and zirconia calcine were successfully completed by ANSTO and Battelle Energy Alliance, LLC, (BEA) from 2007 to 2010. The results of these trials are presented in Section 4.

The HIP process produces a dense, monolithic waste form with significant volume reduction (as much as $70 \%$ ) over stored calcine. This volume reduction allows for long-term-repository and interimstorage cost savings as compared with direct loading of granular calcine into storage/disposal casks. The estimated long-term disposition cost of a single waste canister is \$620,000 (ANSTO and INL 2009).

According to a 2004 joint study between ANSTO and INL, using the HIP process for volume reduction for both INTEC granular calcine and solidified sodium-bearing waste would save an estimated \$2 billion in disposal costs (a 50\% reduction) over the previous DOE baseline treatment of vitrification and immobilization in a borosilicate glass matrix (Begg et al. 2005). HIP technology is expected to reduce the disposal volume by 20 to $70 \%$ and produce a calcine waste product with comparable or better durability than the vitrification process (DOE-ID 2010).

The next step in development of the HIP process to dispose of HLW calcine is completion of a HIP treatability study using actual INTEC calcine. BEA has identified INTEC calcine material to use for a treatability study and has developed equipment and procedures to transport and handle the calcine prior to HIP processing.

Risks associated with radioactive and hazardous constituent release, post-production handling, and long-term storage are reduced through use of the HIP process. The required number of waste shipments is reduced by an amount scalable with the volume reduction, which is another result with inherent risk reduction. Additionally, the waste monolith can provide up to a million-fold reduction in waste surface area as compared to a granular product, reducing the opportunity for aqueous release of calcine waste into the environment (ANSTO and INL 2009). In December 2009, based on favorable results of HIP trials, the DOE amended its Record of Decision (ROD) initially published in 2005 pursuant the Idaho High-Level Waste and Facilities Disposition Final Environmental Impact Statement (EIS) (DOE/EIS-0287) and selected HIP technology to treat calcine HLW. HIP technology was chosen over several other treatment options identified in the EIS because it is anticipated to cost-effectively treat the waste, reduce its volume, and place the waste in a form ready to be moved out of the state of Idaho consistent with the dates in the Idaho Settlement Agreement (State of Idaho 1995). The target date for completion of calcine treatment is December 31, 2035 (75 FR 1).

\section{HIP INDUSTRIAL BACKGROUND AND PREVIOUS INL WORK}

The HIP process was originally developed in the 1930s and patented in 1941 by Johann Romp of the Phillips Corporation (Insaco, Inc., 2012; Shaw et al. 2012). The HIP process uses high pressure combined with heat to reduce the void spaces within materials, thereby improving material properties such as strength and ductility. Components to be pressed are placed inside of a pressure vessel containing an 
electrically heated furnace. The contents are heated and pressurized isostatically (uniformly on all sides) with an inert gas such as argon (Figure 3). The HIP process eliminates the material's internal porosity without changing the shape of the item. HIP process temperatures and pressures can be as high as $2000^{\circ} \mathrm{C}$ and 60,000 psi, respectively (Insaco, Inc., 2012).

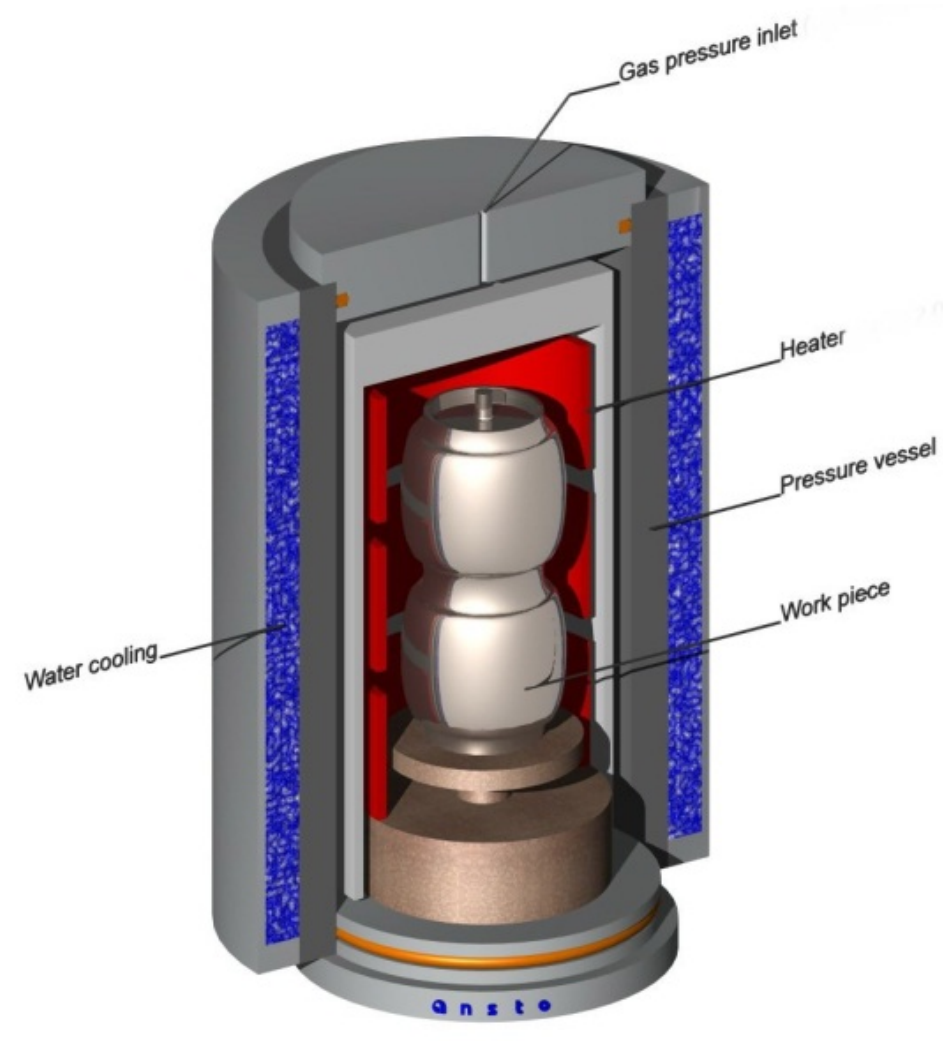

Figure 3. Standard HIP schematic (ANSTO and INL 2009).

Beginning in 1955, Battelle began research into the HIP process as a means of bonding components of small zircaloy-clad, pin-type nuclear elements while maintaining strict dimensional control and, as a result, patented a HIP process in 1964 to diffusion-bond nuclear fuel. The HIP process is used industrially to consolidate powdered metals for the creation of mechanical components with improved properties. The process is also used to create complex shapes that cannot be fabricated by conventional means. Additionally, already fabricated components can be improved through the HIP process. Examples include removing the flaws created by steel-making rollers, enhancing fatigue resistance in castings by healing defects, and healing defects in used components (ASME 1985).

In the 1990s, a Model MIH-9 pilot-scale HIP manufactured by ABB Autoclave Systems, Inc., was installed in the Hot Fuel Examination Facility (HFEF) decontamination cell at INL's Materials and Fuels Complex (MFC). Since that time, extensive targeted research and pilot-scale testing have been conducted regarding use of the HIP process as a method for treatment of INTEC waste. This research and testing produced a volume-reduced, monolithic waste form with increased stability for disposal in a repository.

Materials to be HIP processed at HFEF are first placed inside stainless-steel or aluminum cans, which are evacuated, sealed (Shaw et al. 2012), and then placed inside a furnace equipped with a molybdenum heating element capable of achieving temperatures up to $1,450^{\circ} \mathrm{C}$ (Figure 4). The furnace is installed inside of a forged pressure vessel rated for $207 \mathrm{MPa}$ with penetrations in the lower closure for gas and 
electrical lines (Bateman and Rigg 1999). The vessel is pressurized by a Hydro-Pac Model IC30-05-2CX electrohydraulic compressor. Six gas cylinders that are connected through a manifold supply argon to the system. Control valves are installed to regulate pressure and provide system venting. The HIP is equipped with a vacuum pump to remove residual air prior to pressurization. Electrical services and cooling water are supplied by the HFEF. The system can be lifted and/or handled with an overhead crane, a master slave manipulator, or an electro-mechanical manipulator (Bateman and Rigg 1999). A large oval yoke weighing almost 2 tons holds the top and bottom end plugs of the vessel in place to maintain pressure. The yoke is positioned by a hydraulic ram (Figure 4) located at the bottom of the yoke near the floor (Bateman, Rigg, and Wiest 2002). The hydraulic system is used to move the system frame and closure to the desired positions for loading and unloading. With the frame retracted and the upper closure opened, the vessel can be loaded and unloaded (Bateman and Rigg 1999).

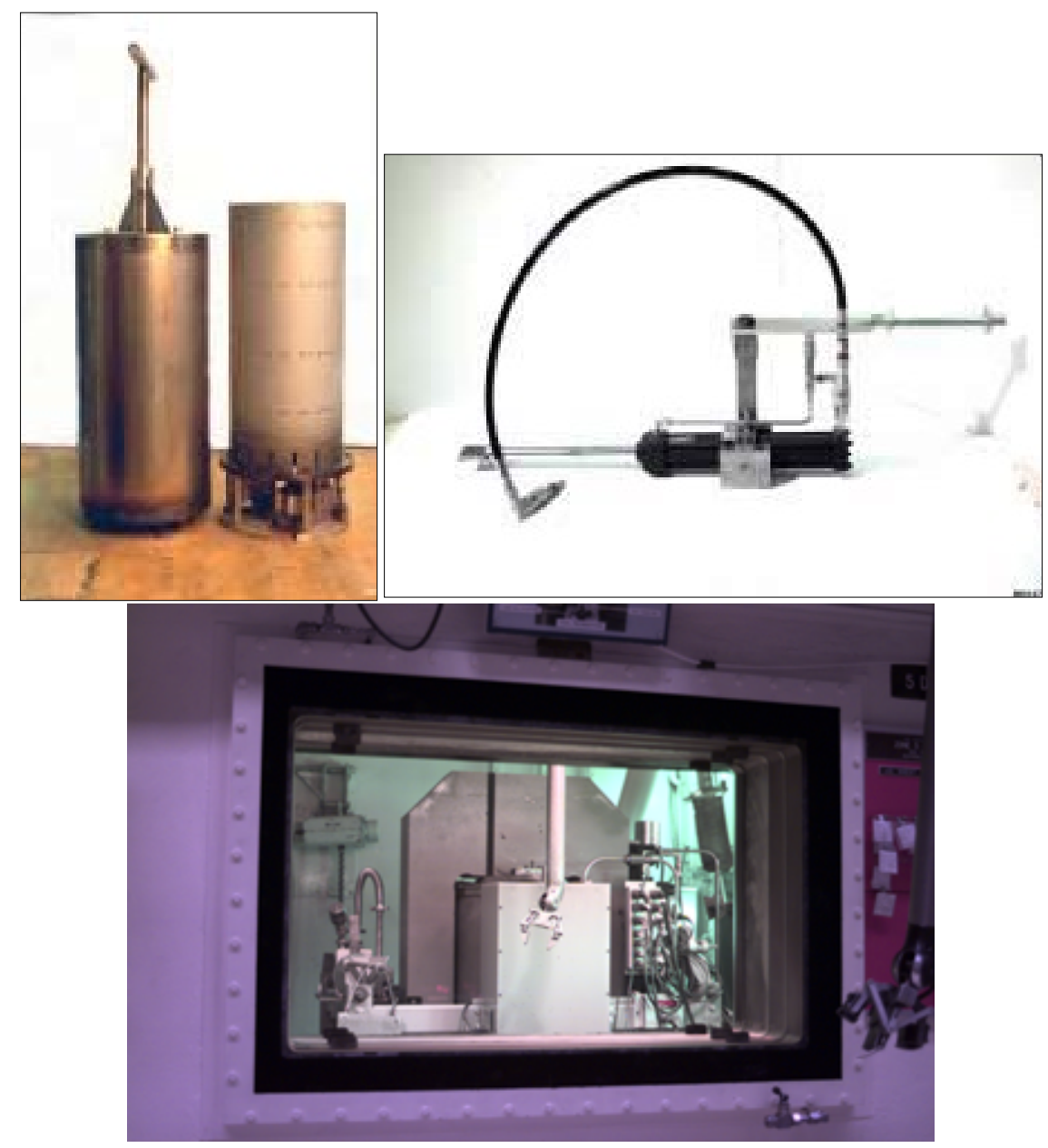

Figure 4. Thermal barrier and furnace (upper left). Hydraulic ram (upper right) used to position the yoke over the pressure vessel. HIP installed in the HFEF Hot Cell (bottom) (Bateman, Rigg, and Wiest 2002).

Ceramic waste forms and plutonium oxides have been successfully processed through the HIP at HFEF. In 2007, BEA began assessment of the HIP process to focus on "challenging" or "orphan" waste forms. Since that time, iodine, corroded fuel pins, irradiated materials, and sludge - in addition to INTEC calcine simulant- have been processed successfully. 


\section{OVERVIEW OF CALCINE TRIALS}

BEA collaborated with ANSTO to produce nonradioactive granular calcine simulant to be used as a raw material in trials to assess the viability of HIP processing of calcine waste (ANSTO and INL 2009). Simulated alumina and zirconia calcines, both of which contained full RCRA heavy-metal components designed to mimic the properties of INTEC calcine, were produced in a pilot-scale fluidized bed calciner. Simulant calcine liquid feed compositions were based on historical process model data provided by the current Environmental Management contractor managing the INTEC facility, i.e., CH2M-WG Idaho (CWI), and reflect actual calcination runs of historical calcine waste. Because of the variability of RCRA components in INTEC calcine, specifically mercury in alumina calcine and cadmium in zirconia calcine, three separate variants of each surrogate calcine composition were prepared. Mercury and cadmium concentrations in alumina and zirconia calcine, respectively, were varied - from baseline concentrations through a transition to a maximum concentration. All other RCRA components were kept constant and at maximum concentrations (ANSTO and INL 2009).

To demonstrate the waste-reduction advantages that HIP treatment would provide as compared to direct disposal of raw calcine, the volume of HIP-treated calcine simulant was compared with the volume of raw calcine simulant for each trial. The Product Consistency Test (PCT) and Toxic Characteristic Leaching Procedure (TCLP) testing were performed on the HIP-treated calcine to determine its durability and RCRA hazardous waste characteristics. TCLP tests also were performed on raw calcine simulant to determine RCRA characteristics for the calcines prior to HIP processing.

Data from TCLP leachability tests conducted on raw alumina and zirconia calcines with baseline, transition, and maximum RCRA metals concentrations were compared to the constituent-specific Universal Treatment Standard (UTS). None of the simulated calcines passed the UTS, with multiple elements failing for each surrogate.

Several variations of calcine HIP trials were performed. Direct HIP processing was the method that provided the highest effective (storage) volume reduction as compared with raw calcine simulant. Treated HIP processing, i.e., blending the calcine simulant with an additive prior to HIP processing, improved the TCLP and PCT results of the HIP-processed calcine simulant. Scaled-up (25 kg and $180 \mathrm{~kg}$ ) HIP trials were also performed. Finally, a trial was conducted using alumina calcine simulant that was spiked with radionuclides prior to HIP processing. A summary of HIP trials and characterization tests performed on calcine simulant appears in Table 1.

Table 1. Summary of HIP trials conducted by ANSTO and INL.

\begin{tabular}{|l|l|l|}
\hline \multicolumn{1}{|c|}{ HIP Treatment } & \multicolumn{1}{c|}{ Raw Calcine Simulant(s) } & \multicolumn{1}{c|}{ Characterization } \\
\hline $\begin{array}{l}\text { Raw Calcine (Not HIP } \\
\text { Processed) }\end{array}$ & $\begin{array}{l}\text { Baseline, Transition, and Maximum } \\
\text { RCRA Alumina and Zirconia Calcines }\end{array}$ & TCLP \\
\hline Direct HIP & $\begin{array}{l}\text { Maximum RCRA Alumina and } \\
\text { Zirconia Calcines }\end{array}$ & $\begin{array}{l}\text { TCLP, PCT, Scanning Electron } \\
\text { Microscopy, X-Ray Diffraction }\end{array}$ \\
\hline Treated HIP & $\begin{array}{l}\text { Baseline, Transition, and Maximum } \\
\text { RCRA Alumina and Zirconia Calcines }\end{array}$ & $\begin{array}{l}\text { TCLP, PCT, Scanning Electron } \\
\text { Microscopy, X-Ray Diffraction }\end{array}$ \\
\hline Scaled-up Treated HIP & Blended RCRA Alumina Calcine & $\begin{array}{l}\text { TCLP, PCT, Scanning Electron } \\
\text { Microscopy, X-Ray Diffraction }\end{array}$ \\
\hline $\begin{array}{l}\text { Radionuclide-Spiked } \\
\text { Material HIP }\end{array}$ & Maximum RCRA Alumina Calcine & TCLP \\
\hline
\end{tabular}




\section{SIMULANT CALCINE HIP PROCESSING RESULTS}

Cans filled with calcine simulants were HIP processed at both ANSTO and the INL, where the HIP in the HFEF hot cell at MFC was used. Prior to HIP processing, samples were baked out at temperatures between 500 and $900^{\circ} \mathrm{C}$ to remove volatiles. Each surrogate calcine monolith was HIP processed at a maximum pressure of $35 \mathrm{MPa}$. Maximum temperatures ranged between 1,050 and $1,200^{\circ} \mathrm{C}$.

Direct HIP processing resulted in volume reductions of nearly $70 \%$ for alumina calcine and approximately $50 \%$ for zirconia calcine as compared with raw calcine simulants. TCLP samples of the HIP-processed alumina calcine simulant passed the TCLP UTS, but all PCT samples, as well as TCLP samples of zirconia calcine, failed to meet treatment standards. Though not all direct HIP-processed samples passed treatment standards, the product of direct HIP processing is much more durable than raw calcine simulant. The surface area of the simulated waste form is several orders of magnitude less than that of the raw calcine simulant, representing a waste form with less risk for aqueous release to the environment.

Addition of treatment additives to the raw calcine product prior to HIP processing improved the durability of the HIP-processed product when compared with direct HIP processing without treatment additives. With a 77\% calcine simulant loading, all treated alumina samples, including a scaled-up (30x) sample, met both TCLP and PCT treatment standards following HIP processing. Effective volume reductions following treated HIP processing of alumina nearly matched those of direct HIP-processed alumina calcine. All treated zirconia calcine simulant trials using a 60\% calcine loading met TCLP (UTS) and PCT (environmental assessment [EA] glass) standards after HIP processing. Treated zirconia calcine HIP trials resulted in less effective volume reductions than direct HIP-processed samples, but one scoping trial showed promising results toward optimizing processing parameters to simultaneously maximize volume reduction while meeting treatment standards. One treated alumina calcine simulant sample was spiked with radionuclides prior to HIP processing. The effective volume reduction was greater than $50 \%$. A TCLP sample obtained from the HIP-processed sample met the UTS.

\subsection{Direct HIP Processing}

Direct HIP processing was performed on maximum RCRA alumina and zirconia raw calcine. Two trials were completed for each type of calcine (Table 2). Direct HIP-processed calcine simulant exhibited volume reductions of nearly $70 \%$ for alumina and approximately $50 \%$ for zirconia calcine. Volume reduction data show TCLP samples of the direct HIP-processed alumina calcine met the UTS standard. Although TCLP samples of zirconia calcine and PCT samples of alumina and zirconia calcines failed to meet standards, direct HIP processing produced a monolith with increased durability and reduced the surface area by multiple orders of magnitude as compared with raw calcine simulant (Figure 5). The volume reductions for the two alumina calcine trials were within $2 \%$ of each other. The zirconia calcine effective volume reduction trials differed by only $1 \%$, demonstrating the consistency of the HIP process.

Table 2. Summary of surrogate calcine direct HIP trials (ANSTO and INL 2009).

\section{Direct HIP Demonstration}

\begin{tabular}{|l|c|c|c|c|}
\hline \multicolumn{1}{|c|}{ Calcine Simulant } & $\begin{array}{c}\text { Alumina } \\
\text { Max RCRA }\end{array}$ & $\begin{array}{c}\text { Alumina } \\
\text { Max RCRA }\end{array}$ & $\begin{array}{c}\text { Zirconia } \\
\text { Max RCRA }\end{array}$ & $\begin{array}{c}\text { Zirconia } \\
\text { Max RCRA }\end{array}$ \\
\hline Maximum HIP Process Temperature $^{*}$ & $1,200^{\circ} \mathrm{C}$ & $1,200^{\circ} \mathrm{C}$ & $1,050^{\circ} \mathrm{C}$ & $1,050^{\circ} \mathrm{C}$ \\
\hline HIP Volume Reduction $^{*}$ & $\mathbf{6 9 \%}$ & $\mathbf{6 7 \%}$ & $\mathbf{5 0 \%}$ & $\mathbf{5 1 \%}$ \\
\hline
\end{tabular}


Table 2. (continued).

\begin{tabular}{|l|c|c|c|c|}
\hline \multicolumn{5}{|c|}{ Direct HIP Demonstration } \\
\hline \multicolumn{1}{|c|}{ Calcine Simulant } & $\begin{array}{c}\text { Alumina } \\
\text { Max RCRA }\end{array}$ & $\begin{array}{c}\text { Alumina } \\
\text { Max RCRA }\end{array}$ & $\begin{array}{c}\text { Zirconia } \\
\text { Max RCRA }\end{array}$ & $\begin{array}{c}\text { Zirconia } \\
\text { Max RCRA }\end{array}$ \\
\hline Characterization & \multicolumn{3}{|l}{} \\
\hline PCT (EA Standard) & Fail & Fail & Fail & - \\
\hline TCLP (UTS) & Pass & Pass & Fail & - \\
\hline
\end{tabular}

*Effective volume reduction as compared to raw calcine simulant.

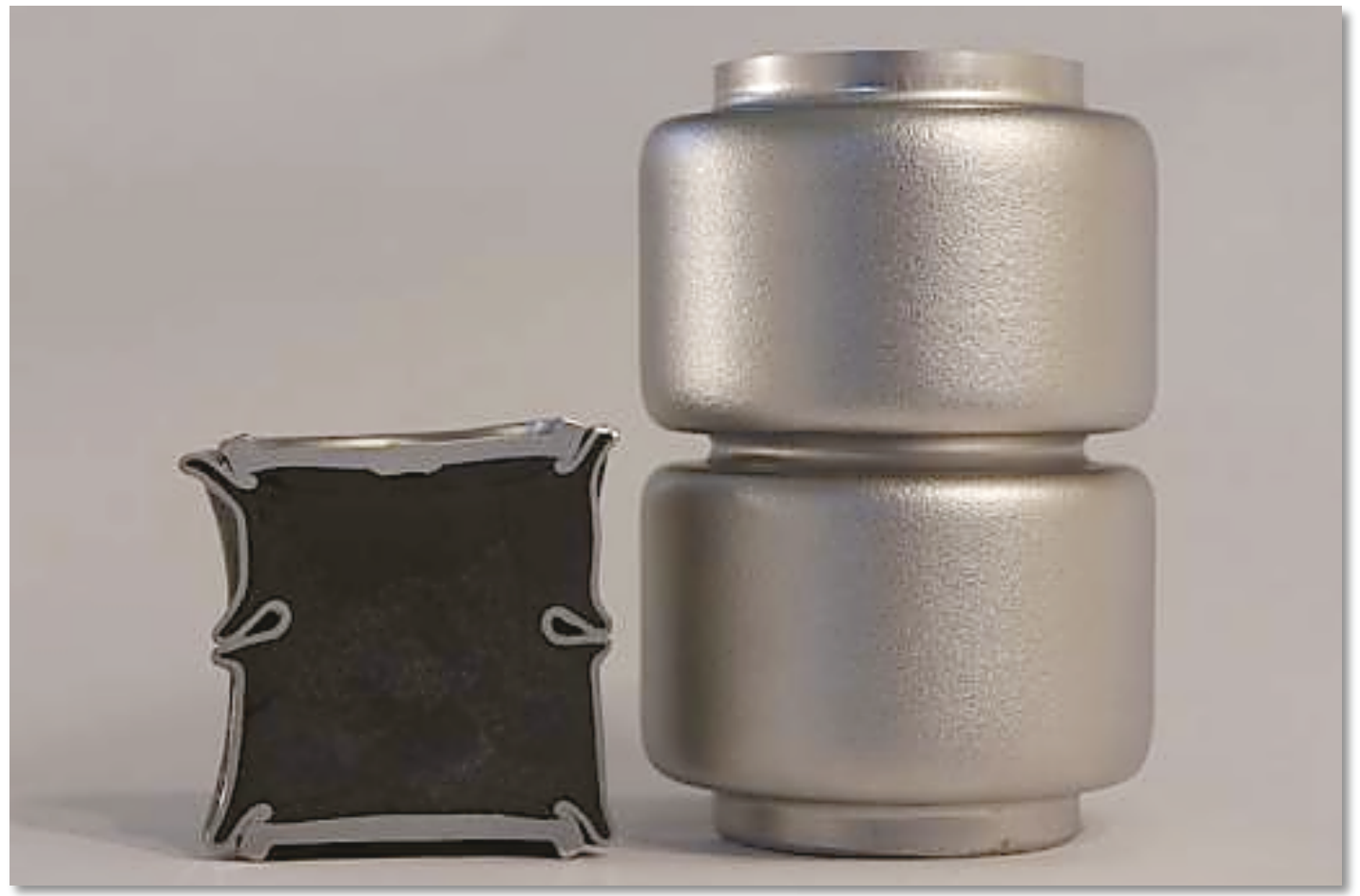

Figure 5. Direct HIP-processed alumina calcine simulant (ANSTO and INL 2009).

\subsection{Treated Alumina Calcine}

Treated HIP demonstrations were performed on alumina calcine simulant at baseline, transition, and maximum RCRA metals concentrations. For each trial, raw alumina calcine simulant was blended with proprietary treatment additives to improve the durability characteristics of the HIP-processed product. All treated samples were prepared with a loading of $77 \mathrm{wt} \%$ raw calcine simulant and $23 \%$ treatment additives. The maximum temperature during HIP processing for all treated alumina calcine trials was $1,150^{\circ} \mathrm{C}$.

Through HIP processing, a more durable simulated waste product was formed (Figure 6) as compared to direct HIP-processed alumina calcine simulant. HIP-processed treated alumina simulant met both the TCLP and PCT standards (Table 3) with only slightly less volume reduction than direct HIP-processed alumina simulant. The effective volume reduction as a result of HIP processing varied from 60 to $66 \%$ for treated alumina simulant and showed the repeatability of the HIP process, even across different RCRA constituent concentrations. Scanning electron microscopy and x-ray diffraction indicated that in all cases 
the predominant phases in HIP-processed treated alumina calcine simulant were alumina set within a refractory glass matrix (ANSTO and INL 2009).

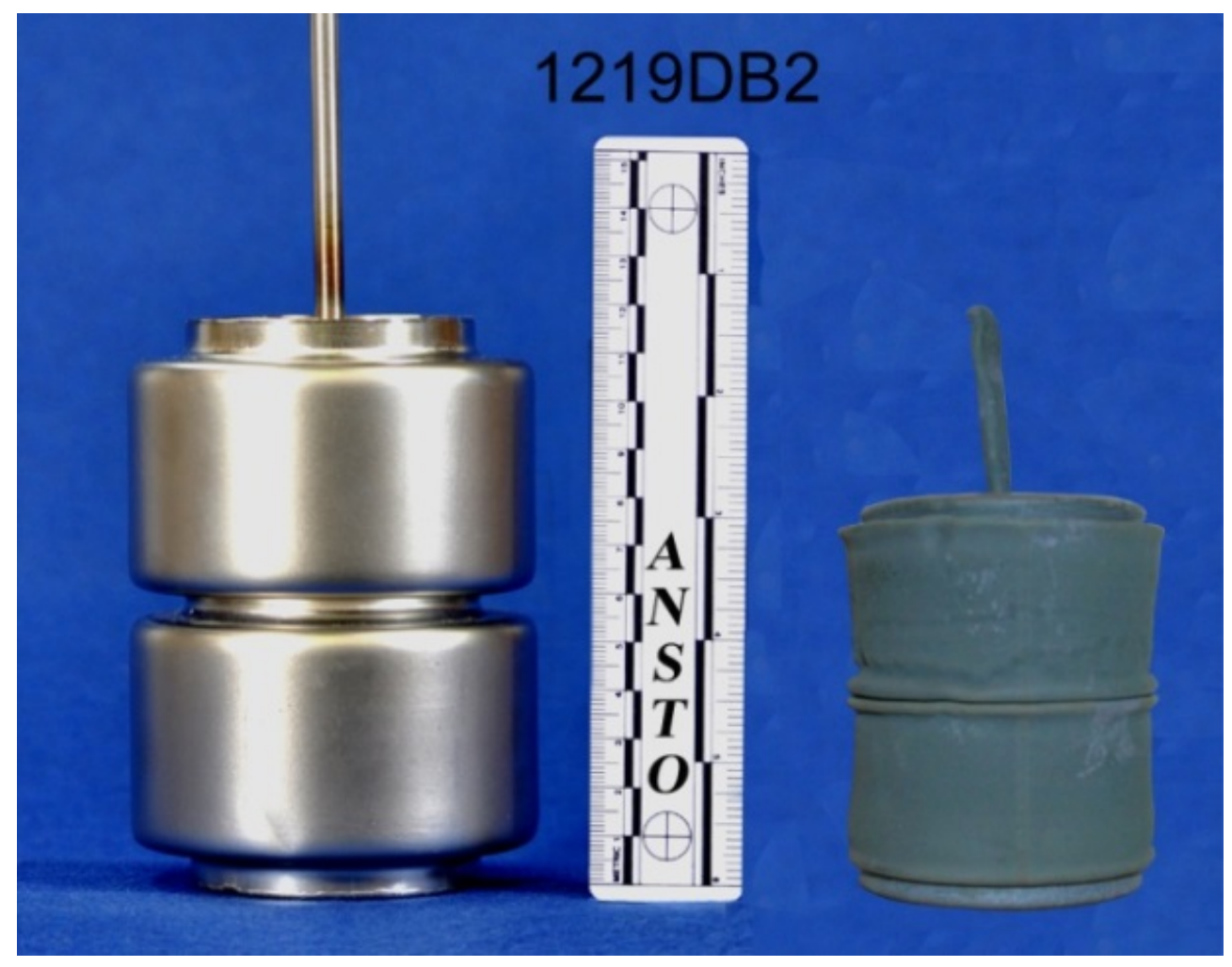

Figure 6. Photograph of treated maximum RCRA alumina simulant calcine sample before and after HIP processing (ANSTO and INL 2009).

Table 3. Summary of treated alumina calcine simulant HIP trials (ANSTO and INL 2009).

\begin{tabular}{|l|c|c|c|}
\hline \multicolumn{1}{|c|}{ Calcine Simulant } & $\begin{array}{c}\text { Alumina Baseline } \\
\text { RCRA }\end{array}$ & $\begin{array}{c}\text { Alumina } \\
\text { Transition RCRA }\end{array}$ & $\begin{array}{c}\text { Alumina Max } \\
\text { RCRA }\end{array}$ \\
\hline $\begin{array}{l}\text { Maximum HIP Process } \\
\text { Temperature }\end{array}$ & $1,150^{\circ} \mathrm{C}$ & $1,150^{\circ} \mathrm{C}$ & $1,150^{\circ} \mathrm{C}$ \\
\hline $\begin{array}{l}\text { Weight \% (Raw Calcine } \\
\text { Simulant) }\end{array}$ & $77 \%$ & $77 \%$ & $77 \%$ \\
\hline HIP Volume Reduction* & $\mathbf{6 0 \%}$ to 65\% & $\mathbf{6 1 \%}$ to $\mathbf{6 5 \%}$ & $\mathbf{6 1 \%}$ to $\mathbf{6 6 \%}$ \\
$\mathbf{( 4}$ trials $)$ & $\mathbf{( 2 \text { trials } )}$ & trials) \\
\hline Characterization & Pass & Pass & Pass \\
\hline PCT (EA Standard) & Pass & Pass & Pass \\
\hline TCLP (UTS) & &
\end{tabular}

*Effective stored volume reduction as compared to raw calcine simulant. 


\subsection{Treated Zirconia Calcine}

Zirconia calcine is representative of $75 \%$ of the calcine stored at INTEC. Treated zirconia calcine simulant was blended with additives prior to HIP processing. The raw calcine simulant weight percentage was $80 \%$ for baseline RCRA concentrations and $60 \%$ for transition and maximum RCRA concentrations.

Five HIP trials were conducted for treated baseline RCRA zirconia with effective volume reductions between 35 and 43\% (Table 4). TCLP and PCT testing showed that all samples passed the UTS and EA glass chemical durability standard by at least an order of magnitude. For all treated zirconia calcine simulants, scanning electron microscopy and $\mathrm{x}$-ray diffraction indicated that the phase assemblage consisted predominantly of calcium fluoride and zirconia set in a borosilicate glass matrix (ANSTO and INL 2009).

Pretreatment prior to HIP processing was utilized to allow treated transition and maximum RCRA zirconia calcine simulant to meet durability standards. Two different types of pretreatment were employed. The first cadmium pretreatment approach was distillation to remove a proportion of cadmium prior to HIP processing. The second pretreatment method was to increase the reactivity of the calcine by reducing the mean particle size (ANSTO and INL 2009).

For the transition RCRA zirconia calcine simulant, distillation was the only pretreatment option demonstrated. Samples exhibited a volume reduction of $\sim 16 \%$, compared to the as-stored calcine (Table 4). The samples readily passed the EA glass and UTS chemical durability requirements. Results were similar for distillation pretreated samples with maximum RCRA concentrations (Figure 7 and Table 4). HIP-processed samples that were pretreated by particle size reduction passed durability tests with average effective volume reductions of $10 \%$.

In a scoping trial, the calcine simulant weight percentage was increased to $80 \%$. In this trial, maximum RCRA zirconia calcine simulant was pretreated by a combination of distillation and particle size reduction. The HIP-processed sample exhibited an effective volume reduction of $33 \%$, greatly improving upon the volume reduction results for $60 \%$ zirconia calcine simulant loading. The sample met the PCT EA glass durability standard by more than 1 order of magnitude and nearly met the TCLP UTS requirement, failing by less than a factor of 3 (ANSTO and INL 2009). This is a promising result in determining the process conditions to maximize volume reduction while meeting durability standards for zirconia calcines. Further exploration of varying pretreatment conditions and calcine simulant weight percentages (loading) appears promising. 


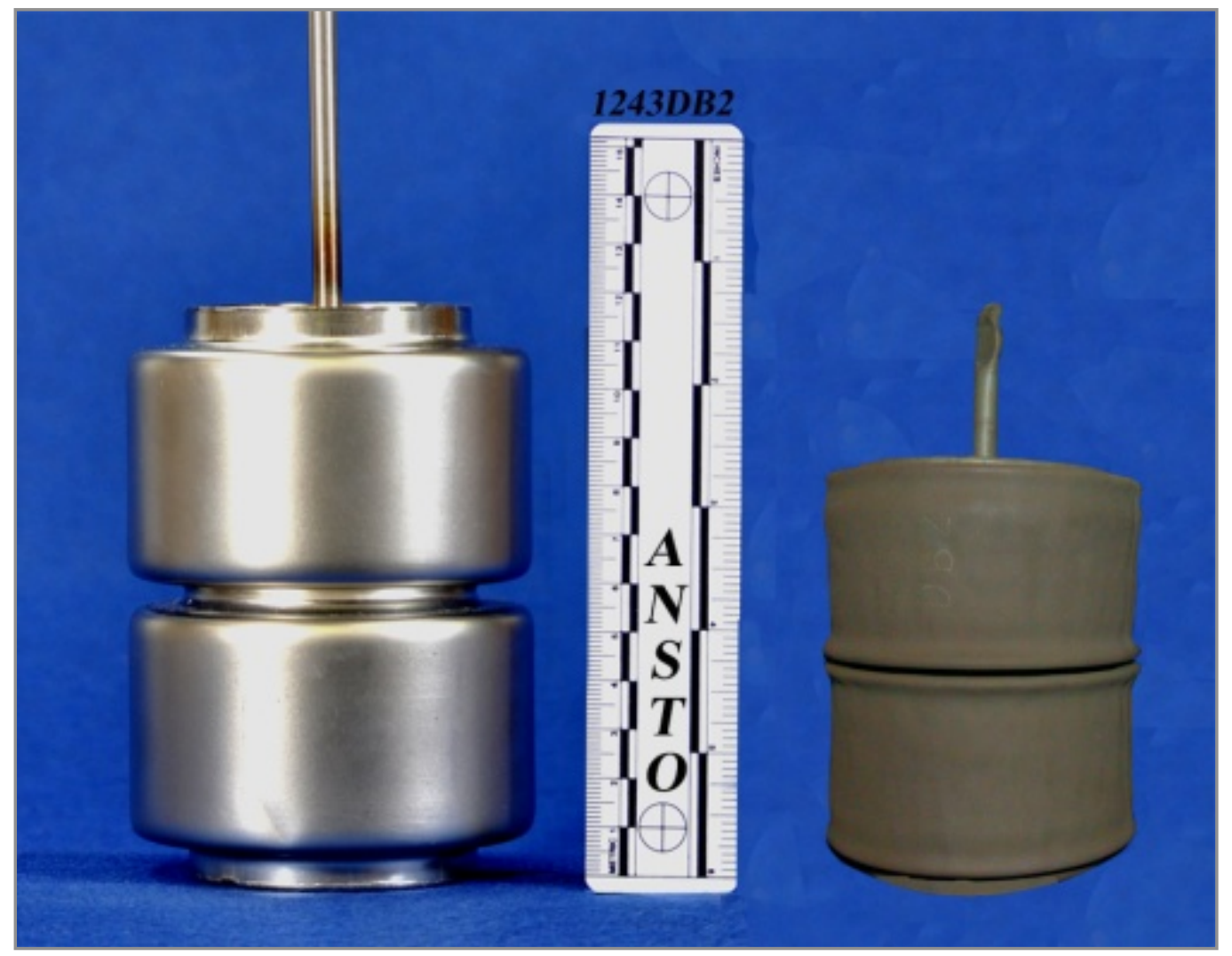

Figure 7. Photograph of treated maximum RCRA zirconia calcine simulant sample with a $60 \%$ raw calcine simulant loading, produced via a distillation route, before and after HIP processing (ANSTO and INL 2009). 


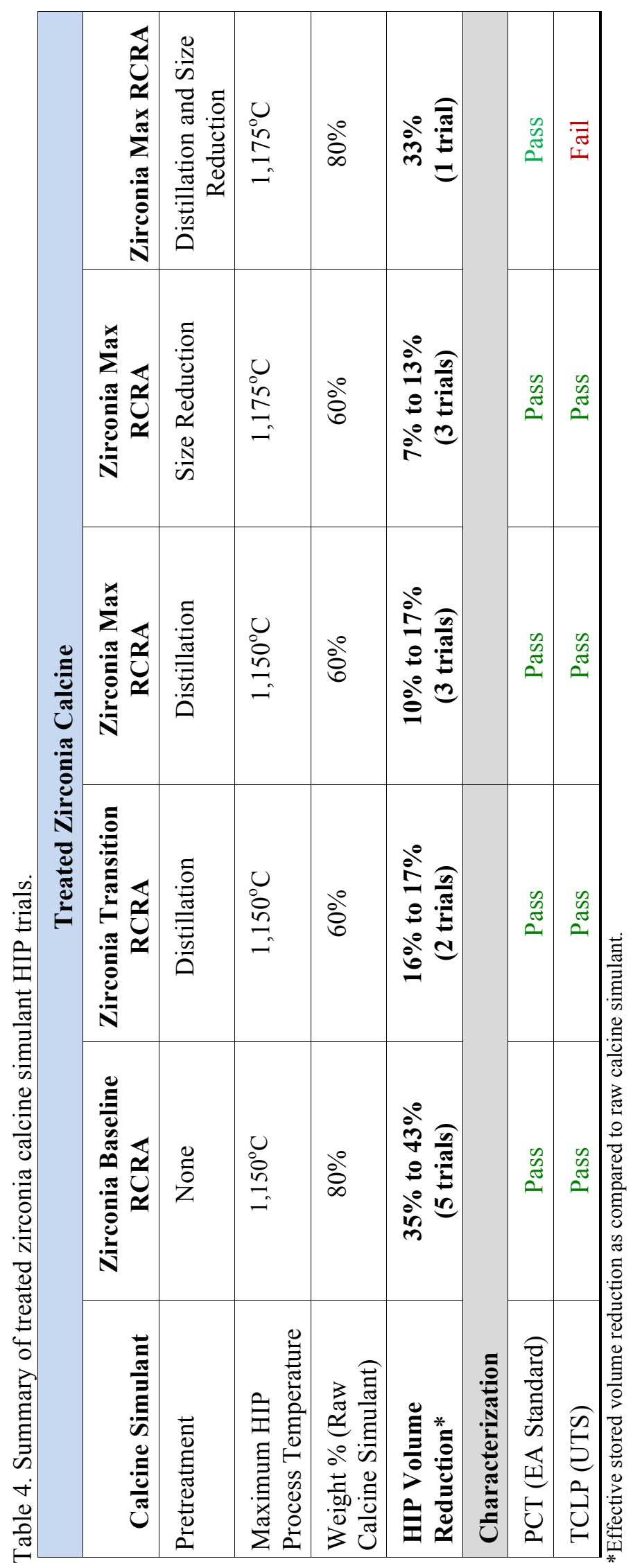




\subsection{Scale-Up Testing - Treated Alumina Calcine}

To demonstrate scalability of the HIP process for INTEC calcine, a $25-\mathrm{kg}$ (nominal) HIP can was prepared using a blend of the alumina calcine simulant and treatment additives. This is a 30 -fold scale-up over the alumina treatability demonstration samples presented above. Two smaller witness cans $(\sim 700 \mathrm{~g})$ were produced with identical material under the same process conditions to benchmark the performance of the $25-\mathrm{kg}$ can. A raw alumina calcine simulant loading of $77 \mathrm{wt} \%$ (23\% treatment additives) was used for all trials (ANSTO and INL 2009).

All HIP-processed cans exhibited effective stored volume reductions of $\sim 65 \%$ (see Figure 8 and Table 5). The volume reductions for all three cans were in excellent agreement with each other and with the 60 to $65 \%$ reported for previous alumina calcine HIP processing trials (ANSTO and INL 2009).

The HIP can was sectioned to obtain a vertical slice for characterization. To gauge sample homogeneity, characterization samples were taken from the top, middle, and bottom regions of the vertical slice. X-ray diffraction and scanning electron microscopy indicated that there was no significant difference in crystalline phases between sample regions or the witness samples. In all instances, the predominant phases were alumina set within a glass matrix (ANSTO and INL 2009).

TCLP testing was performed on samples taken from each section of the vertical slice using $10-\mathrm{g}$ samples and larger 100-g samples. The test results confirm that all samples passed the UTS requirements for all RCRA components. Duplicate PCT testing indicated that samples from each region consistently passed the EA glass standard. These results confirm that the HIP process used to treat blended RCRA alumina calcine is scalable to a factor of $\sim 30$ times (ANSTO and INL 2009).
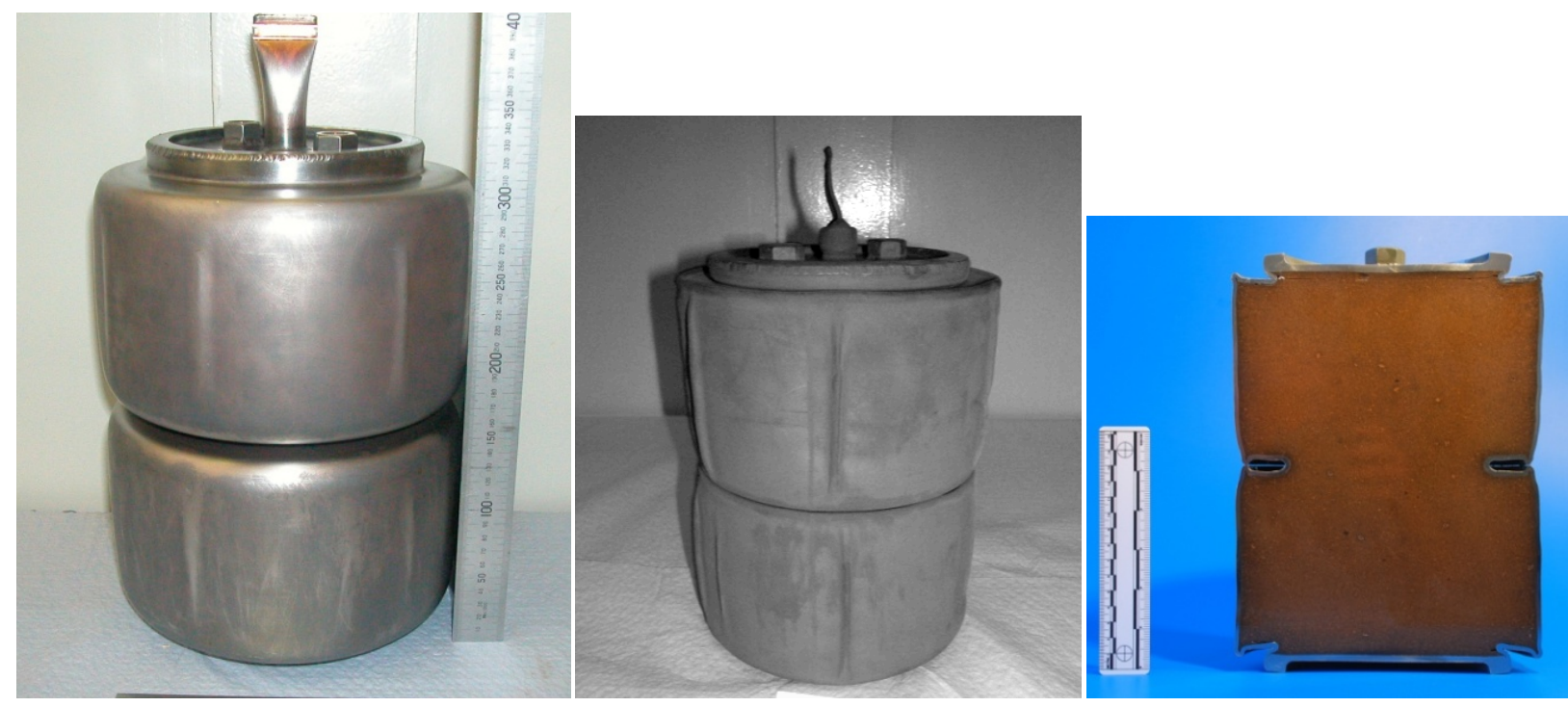

Figure 8. Photographs of scale-up treated alumina simulant (from left to right): prior to HIP processing, after HIP processing, and sectioned after HIP processing (ANSTO and INL 2009).

To further demonstrate the scalability of HIP treatment, ANSTO successfully HIP processed $180 \mathrm{~kg}$ of treated alumina calcine simulant (see Figure 9 and Table 5). The $60 \%$ effective volume reduction was consistent with volume reductions found in smaller-scale HIP processing trials and shows that the HIP process can produce a full-scale waste form. 


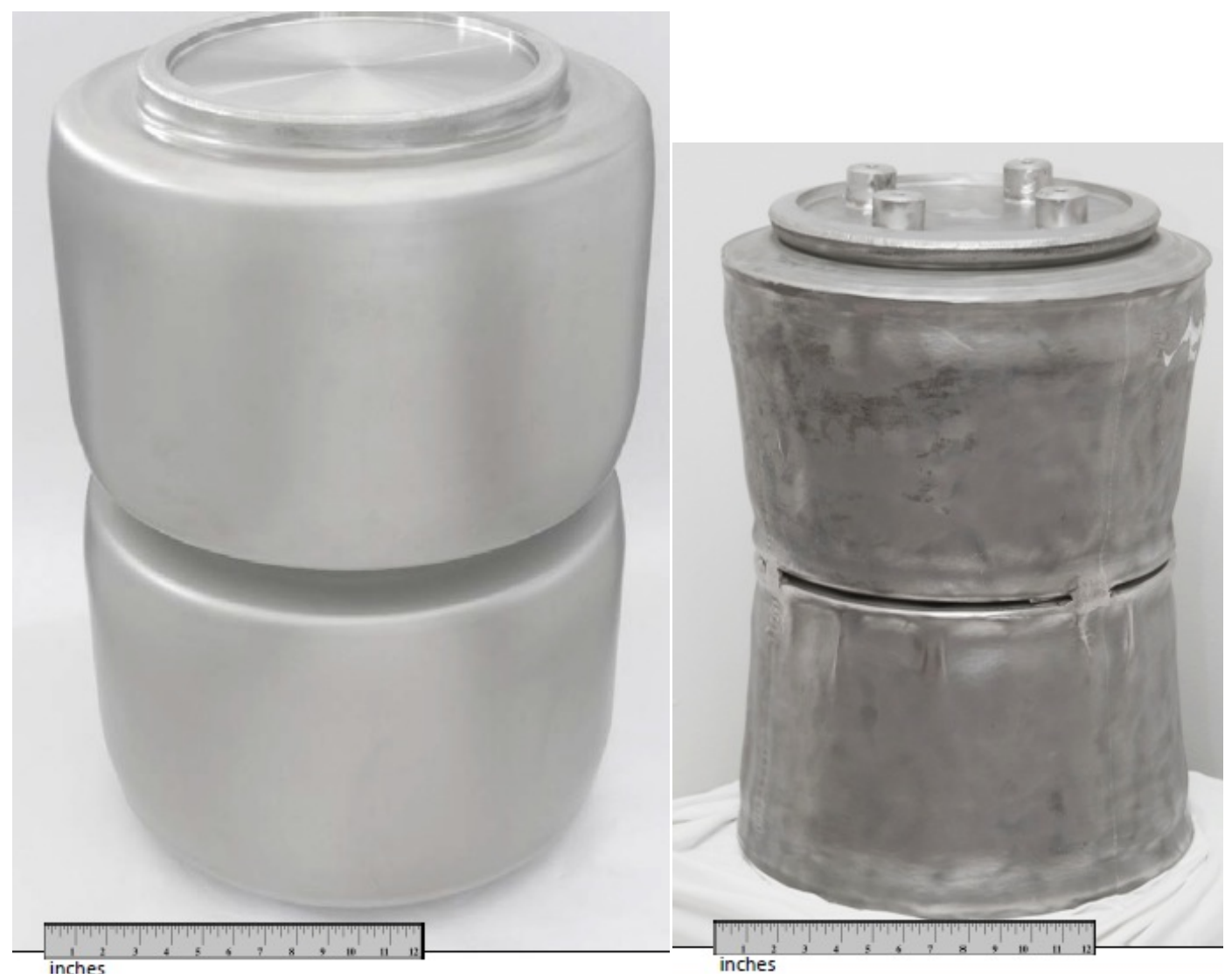

Figure 9. Photographs of industrial-scale treated alumina simulant prior to HIP processing (left) and after HIP processing (right).

Table 5.Summary of treated alumina calcine scale-up trials (ANSTO and INL 2009).

\begin{tabular}{|l|c|c|c|c|}
\hline \multicolumn{5}{|c|}{ Treated Alumina Calcine Scale-Up } \\
\hline \multicolumn{1}{|c|}{ Calcine Simulant } & $\begin{array}{c}\text { Alumina Blended } \\
\text { RCRA }\end{array}$ & $\begin{array}{c}\text { Alumina Blended } \\
\text { RCRA }\end{array}$ & $\begin{array}{c}\text { Alumina Blended } \\
\text { RCRA }\end{array}$ & $\begin{array}{c}\text { Alumina Blended } \\
\text { RCRA }\end{array}$ \\
\hline Material Weight
\end{tabular}

a. Calcine simulant + treatment additive weight.

b. Effective stored volume reduction as compared to raw calcine simulant. 


\subsection{Spiked Material HIP Processing}

To assess the impact of radionuclides on the immobilization of surrogate calcine, ANSTO supplied BEA with a treated maximum RCRA alumina calcine precursor for spiking with a range of actinides prior to HIP processing at HFEF.

The current Environmental Management contractor (CWI) managing the INTEC facility provided information on the type and concentration of radionuclides in the alumina calcine. To present a worst-case demonstration, it was agreed to increase the concentration of spiked components provided by CWI by a factor of 10. The surrogate alumina calcine was spiked with oxides of the following radioactive components: uranium, neptunium, americium, and plutonium. In addition, nonradioactive oxide spikes of cesium, strontium, and ruthenium (representing technetium) were added by ANSTO.

The raw alumina calcine simulant sample was spiked, blended with treatment additives, remotely loaded, and successfully processed within the HFEF Hot Cell facility. Figure 10 shows the radioactive spiked alumina calcine simulant after the HIP process in the HFEF Hot Cell.

The TCLP sample taken after HIP processing passed the UTS standard for RCRA constituents. There is no UTS standard for actinide elements, but, similar to RCRA constituents, the added actinides were measured at very low concentrations in the TCLP leachate solution. Greater than $50 \%$ volume reduction was achieved. This result shows good agreement with results for nonradioactive treated alumina calcine simulants and demonstrates the applicability of HIP processing to radioactive materials.

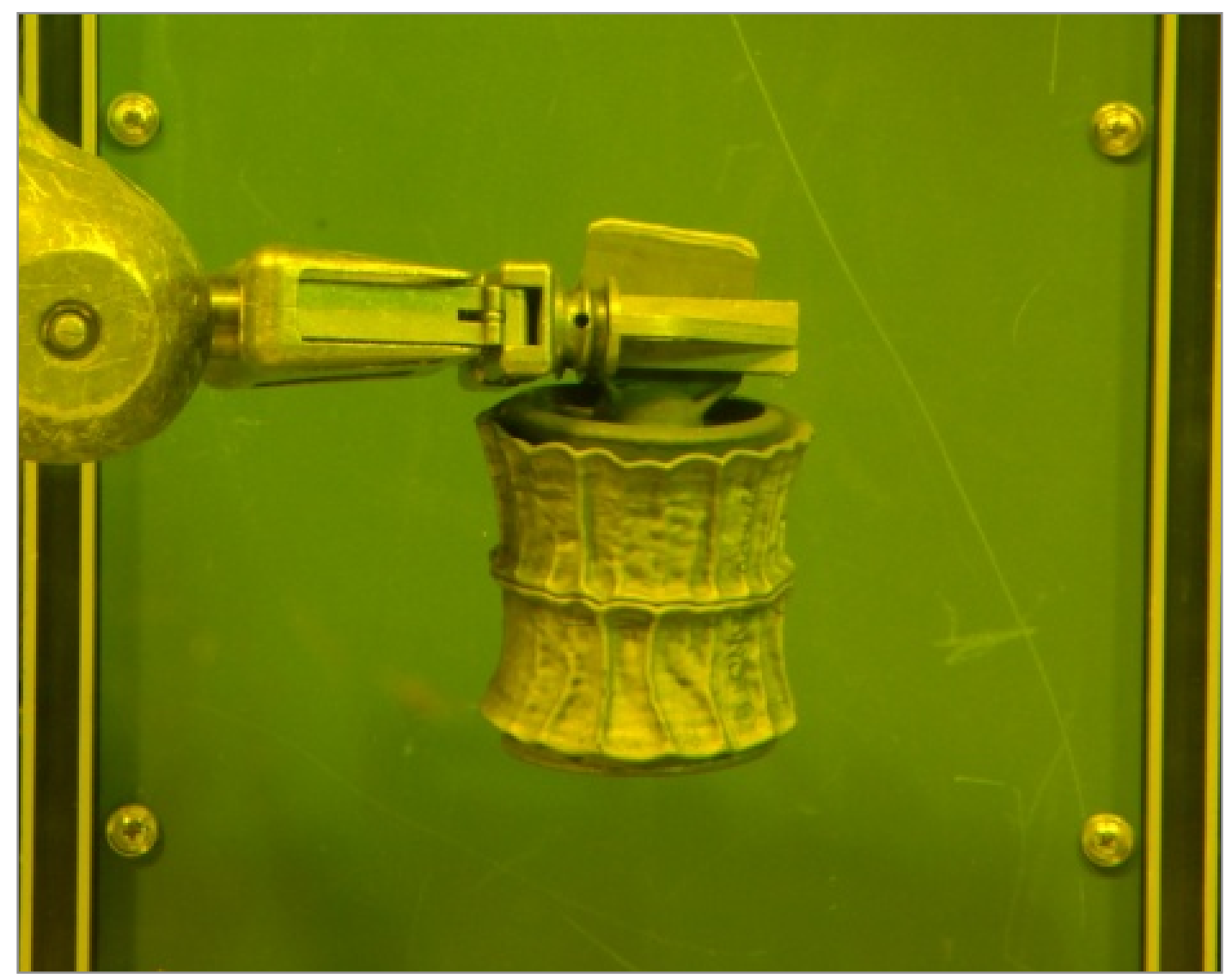

Figure 10. HIP-processed canister of spiked calcine (ANSTO and INL 2009). 


\section{INTEC CALCINE TREATABILITY STUDY}

BEA and ANSTO have successfully completed (a) pilot-scale HIP processing of nonradioactive alumina and zirconia calcine simulants with and without treatment additives, (b) scale-up HIP trials using alumina calcine simulant, and (c) HIP processing of radioactive calcine simulant. The next step in developing HIP processing as a calcine treatment method is to perform a HIP trial using raw calcine generated at INTEC. Prior to funding termination in 2010, BEA had been working toward performing a pilot-scale HIP treatability study of INTEC calcine. Processing had been planned on two 1-gal paint cans of either alumina or zirconia calcine stored within Calcine Sample Storage (CSS) Cask 978 at INTEC (Figure 11). The cask was to be shipped from INTEC to the HFEF at MFC, where it would be stored and prepared for calcine transfer into the hot cell. After HIP operations, the material would be cored and sent for analysis to the MFC analytical laboratory.
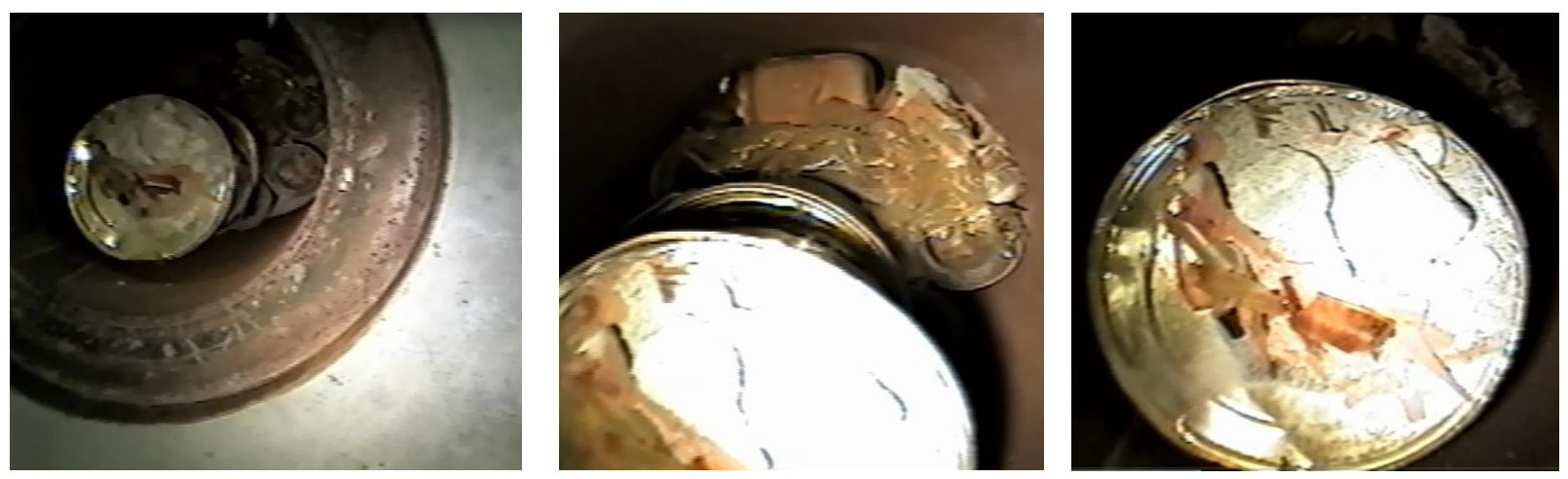

Figure 11. CSS 978 contents as seen in 2003. Note the loose calcine and debris visible in the photograph in the middle and to the right.

Preliminary planning and scoping has already taken place to address the majority of the regulatory and logistical issues associated with the transportation and testing of INTEC calcine. A draft plan documented the regulatory requirements applicable for receiving, treating, and disposing of calcine at MFC. A treatability study notification for INTEC calcine samples issued by BEA was approved by the Idaho Department of Environmental Quality in March 2010. A transportation plan is in place and currently in use by CWI, and an interface agreement between CWI and BEA has been drafted to allow the transport and receipt of calcine.

HFEF has been found to be suitable to conduct CSS cask operations. The HFEF documented safety analysis (BEA 2010a) has been revised to allow for the receipt, transfer, handling, processing, examination, and shipment of calcine. A procedure (BEA 2010b) for handling and unloading the CSS cask was written and became effective November 11,2010 and a fixative material and application method has been identified to control loose surface contamination on samples. A lift fixture designed, fabricated, and tested for transfer of the storage cask and facility cranes would be used to transport the CSS cask once inside of HFEF. The HFEF Preparation Room, a Hazardous Waste Management Act/RCRApermitted unit for storage, was designated for cask storage throughout HIP processing to unloading. After opening the cask, the calcine would be placed into a transparent transfer container for transport into the hot cell. Inside of the hot cell, the calcine can would be opened, and the calcine would be characterized, blended, and HIP processed. BEA has equipment and material designed and tested to perform these operations.

Following HIP processing, in-cell analysis, and material coring, samples would be transferred out of cell and sent to the MFC analytical laboratory for scanning electron microscopy, PCT, and TCLP 
analysis. Waste associated with calcine treatment includes the HIP-processed calcine as well as secondary waste streams generated as a result of HIP processing. Agreements are in place between CWI and BEA for the acceptance of waste streams associated with HIP processing pilot tests. An Integrated Waste Tracking System waste material/container profile has been developed for calcine. MFC laboratory personnel have been briefed and provided with waste disposal documentation for calcine. As of the end of Calendar Year 2010, when project funding was eliminated, the MFC analytical laboratory was ready to receive calcine samples for HIP processing.

Candidate materials have been identified for the treatability study; equipment has been designed, fabricated, and tested; and necessary plans and agreements have either been drafted or issued. BEA has demonstrated the ability to complete the first pilot-scale HIP processing trial of actual INTEC calcine.

\section{CONCLUSIONS}

HIP processing of surrogate calcine performed at both HFEF and ANSTO from 2007 to 2010 demonstrates the significant volume reduction and chemical durability improvement that HIP processing provides over direct disposal. Calcine waste surface area reductions of up to 6 orders of magnitude are achievable for full-scale, HIP-processed calcine when compared with its raw form. This decreases the opportunity for aqueous release of contaminants, minimizing the environmental risks associated with long-term storage.

To date, testing has been completed on raw calcine simulant, direct HIP-processed calcine simulant, treated HIP-processed simulant including scale-up trials, and radionuclide-spiked calcine simulant. In all cases, HIP processing produced a resultant material with greater durability and reduced volume as compared with raw calcine simulant. HIP processing produced effective (storage) volume reductions of calcine simulant ranging from $\sim 10$ to $\sim 70 \%$, minimizing the waste footprint. As a result, long-term (repository) and interim HLW storage cost savings, as compared to direct calcine disposal or other treatment methods, are estimated in the billions of dollars.

Actual INTEC calcine to be processed has been identified, and the equipment, facilities, and preliminary plans are in place to perform a HIP treatability study using INTEC calcine. BEA has the ability to complete pilot-scale HIP processing of INTEC calcine, which is the next necessary step in implementing HIP processing as a calcine treatment method.

\section{REFERENCES}

40 CFR 261, 2013, "Identification and Listing of Hazardous Waste," Code of Federal Regulations, Office of the Federal Register, July 1, 2013.

75 FR 1, 2010, "Amended Record of Decision: Idaho High-Level Waste and Facilities Disposition Final Environmental Impact Statement Revised by State 12/21/09," U.S. Federal Register, Department of Energy, pp. 137-140, January 4, 2010.

42 USC $\S 6901$ et seq., 1976, "Resource Conservation and Recovery Act (Solid Waste Disposal Act)," United States Code, October 21, 1976.

42 USC § 10101 et seq., 1983, "Nuclear Waste Policy Act of 1982," United States Code, January 7, 1983.

ANSTO and INL, 2009, Assessment of Hot Isostatic Pressing (HIP) Annual Report 2009, Executive Summary, ANSTO, Inc., and Idaho National Laboratory, October 2009.

ASME, 1985, The Evolution of HIP, https://www.asme.org/getmedia/1e84f9c1-710e-445c-9f6c7631 ea2af48a/103-First-Hot-Isostatic-Processing-Vessels.aspx, American Society of Mechanical Engineers, April 2, 1985. 
Bateman, K. J. and R. H. Rigg, 1999, "System Design Description Hot Isostatic Press (HIP),” Idaho National Laboratory, Document F3640-0001-AJ-01, March 16, 1999.

Bateman, K. J., R. H. Rigg, and J. D. Wiest, 2002, "Hot Isostatic Pressing of Ceramic Waste from Spent Nuclear Fuel," ICONE 10-22199, Proceedings of ICONE 10, $10^{\text {th }}$ International Conference on Nuclear Engineering, April 14, 2002, to April 18, 2002.

BEA, 2010a, Materials and Fuels Complex HFEF Safety Analysis Report, DSA-003-HFEF, September 14, 2010.

BEA, 2010b, “Calcine Sample Storage Cask,” HFEF-OI-6216, Rev. 1, November 2010.

Begg, B. D., R. A. Day, S. Morricam, M. W. A. Stewart, and E. R. Vance, 2005, "Low Risk Waste Forms to Lock Up High-Level Nuclear Waste," WM-5364, Waste Management 2005 Conference, February 27, 2005, to March 3, 2005.

DOE O 435.1, Chg. 1, 1999, “Radioactive Waste Management,” U.S. Department of Energy, July 9, 1999.

DOE/EIS-0287, Idaho High-Level Waste and Facilities Disposition Final Environmental Impact Statement, U.S. Department of Energy, September 2002.

DOE-ID, 2010, Description and Status of DOE-ID High Level Waste and Plans for Its Storage, Transportation, and Final Disposition: Calcine Disposition Project, U.S. Nuclear Waste Technical Review Board, Full Board Meeting, Idaho Falls, ID, June 29, 2010.

Insaco, Inc., 2012, HIPing - What Is It and What are The Advantages for Engineering Ceramics?, http://www.azom.com/article.aspx?ArticleID=5769\#proc, Web page updated January 11, 2012.

Nelson, L. O. and K. Vinjamuri, 1995, Results of Intermediate-Scale Hot Isostatic Press Can Experiments, Idaho National Engineering Laboratory, INEL-95/0145, May 1995.

Patterson, Michael W. and Allen R. Prather, 2004, D-Cell Calcine Sampling and Analysis, ICP/EXT-04-00423, Rev. 0, August 2004.

Shaw, Steven W., Bruce Begg, Sam Morrica, and Ken Bateman, 2012, Design Features to Facilitate Hot Isostatic Pressing in Remote Shielded Facilities, http://www.merrick.com/merrickandcompany/media/Resources/Nuclear/White\%20papers/HotIsostatic-Pressing-in-Remote-Shielded-Facilities-Rev-0.pdf?ext=.pdf, Merrick \& Company, October 9, 2012.

State of Idaho, 1995, "Settlement Agreement and Consent Order to fully resolve all issues in the actions Public Service Co. of Colorado v. Batt, No. CV 91-0035-S-EJL (D.Id.),” Executed October 16, 1995. 